\title{
Condition assessment and analysis of a reinforced concrete building in India: a case study
}

\author{
N. Anand BE, ME, PhD \\ Associate Professor, Department of Civil Engineering, Karunya Institute of \\ Technology and Sciences, Coimbatore, India (Orcid:0000-0001-7643-9747) \\ (corresponding author: davids1612@gmail.com) \\ Diana Andrushia BE, ME, PhD \\ Assistant Professor, Department of Electronics and Communication \\ Engineering, Karunya Institute of Technology and Sciences, Coimbatore, India \\ (Orcid:0000-0003-0001-2733)
}

Daniel Paul Thanaraj BTech, MTech

Research Scholar, Department of Civil Engineering, Karunya Institute of Technology and Sciences, Coimbatore, India (Orcid:0000-0002-9308-0462)

Prince Arulraj BE, MTech, PhD

Professor, Department of Civil Engineering, Karunya Institute of Technology and Sciences, Coimbatore, India (Orcid:0000-0002-3154-1147)

\begin{abstract}
Structural concrete is a composite material commonly used for the construction of buildings and structures. Reinforced concrete members should be designed for strength, as well as durability. The long service life of the entire structure depends on the durability of concrete. The quality of construction materials, cover to the concrete, exposure conditions and quality of concrete are some of the key factors that affect the durability of concrete. Also, water penetrates easily and finds its way inside concrete through connected pores if the degree of compaction is not proper. Stagnant rainwater in the roof or a high water table may pave the way for the entry of water. The entry of water into structural concrete mainly causes corrosion, thereby reducing the strength of structural elements and initiating the spalling of concrete. A case study based on diagnosis, non-destructive testing and failure analysis of a reinforced concrete building in India is presented. The rehabilitation measures to be undertaken to maintain the service life of the building are also presented.
\end{abstract}

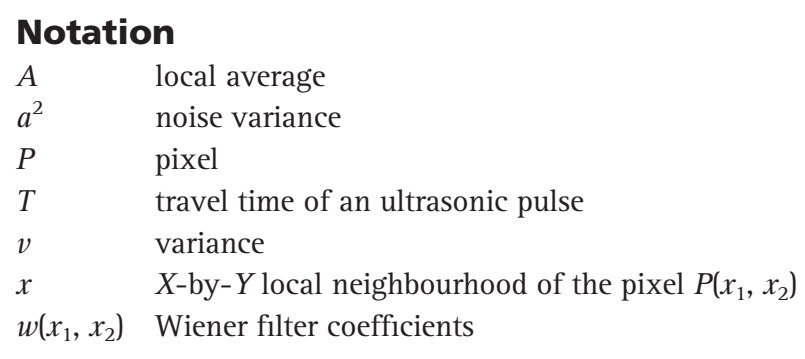

\section{Introduction}

Corrosion of steel bars in reinforced concrete $(\mathrm{RC})$ structures is a significant problem, as it decreases the structural capacity and performance. The decrease in structural capacity is due to the reduction in bond strength and the cross-section of rebars. The decline in performance is due to the cracking of the concrete cover and the increase in deflection.

Corrosion is an electrochemical process that usually affects the reinforcement of concrete structures. The corrosion process is quite complex in nature. Steel rebar is responsible for imparting durability and longevity to concrete. Repair of concrete structures has become necessary, due to the deterioration of concrete and corrosion of embedded steel.

The durability of concrete is important because it showcases the quality of construction. There are many key factors responsible for the reduction in the service life of RC structures. Corrosion of rebar is one of the major factors that affect the durability of concrete. Many studies have been conducted to understand the influence of harmful exposure on concrete (Cui et al., 2017; Li et al., 2011; Qin et al., 2016). It was proven that freezing and thawing, chloride ion penetration and corrosion are common factors that affect the durability of concrete.

Durability is defined as the continued ability of a structure to withstand the expected wear and deterioration and perform satisfactorily under normal operating conditions throughout its intended life without the need for undue maintenance (CPWD, 2002). Surface deterioration, condition of reinforcement and deterioration of finishing materials are some of the assessment parameters. Concrete deteriorates for various reasons, and if visible symptoms such as cracks, leakage and deterioration are observed on the surface, it can be assumed that the interior of the concrete is also damaged. Ignoring these conditions will lead to rapid deterioration of concrete and, hence, a reduction in structural capacity.

Wasim et al. (2020) investigated the long-term corrosion of ordinary, self-compacting and lightweight RC. Specimens were exposed to varying chloride levels and temperatures. Lightweight concrete provided more resistance to corrosion compared with other concretes.

Steel reinforcements are to be protected from aggressive environments.

Generally, the alkaline environment of concrete ( $\mathrm{pH}$ of 12-13) provides protection to steel from corrosion. At high $\mathrm{pH}$ levels, a thin oxide layer forms on the steel and prevents metal atoms from dissolving. However, corrosion can occur when the passive layer is destroyed. The destruction of the passive layer may be due to 
the reduction in the alkalinity of concrete or a considerable increase in the chloride concentration of concrete.

If pore water gets in contact with the passive layer, the protective oxide film is destroyed and corrosion takes place. Also, this process continues as long as oxygen and moisture reach the reinforcement, thus activating the corrosion further.

Many research works are reported in the literature examining the causes and remedies of corrosion in concrete structures. Among all factors, the entry of pore water is one of the major causes of corrosion in concrete structures. This may be due to the entry of storm water and waste water into concrete. The present study explains a case study of a concrete structure that is affected by corrosion due to the entry of pore water. A detailed investigation was carried out and presented based on the tests conducted in the field and laboratory. The entire structure was examined, and the cause of corrosion was identified. Some remedial measures were suggested to maintain the durability of the structure.

\section{Background of the investigation}

In recent years, durability was the major cause of concern regarding distress in buildings. Buildings and structures were designed to withstand sufficient stress. Traditionally, little importance was given to durability requirements.

Among all durability problems, corrosion in concrete structures is considered a major problem. Structures that are affected need systematic inspection and investigation to evaluate the condition of concrete and steel. Corrosion being an electrochemical process, additional parameters such as half-cell potential (HCP), resistivity of concrete and rate of corrosion should also be considered while evaluating the condition of steel and concrete.

Periodic monitoring also plays a vital role in finding out the time to initiation of corrosion and the extent of corrosion (Cairns et al., 2011). Many non-destructive tests are available for detecting the different types of defects and their severity in building elements. Previous research works showed that no particular technique was fully complete and each had its own advantages and limitations (Breysse, 2012; Conde et al., 2017). Anterrieu et al. (2019) performed non-destructive data assimilation as a tool to diagnose the corrosion rate in $\mathrm{RC}$ structures.

The investigated building was a six-storey reinforced concrete framed structure located in Coimbatore District, India. The frame consisted of reinforced concrete beams, columns and slabs with brickwork infill. The building was constructed during the year of 2002. During the stage of investigation, the age of the building was 16 years. Most of the building spaces were used for the long-term storage of goods, except for some spaces that were occupied for office purposes. The building had distress in all floors with cracks in slabs, beams and columns, and reinforcements were also corroded partly/completely. There was no possibility of chloride ingression observed, as there was no source for obtaining chloride atmosphere in the region.
A detailed investigation was carried out on the building by conducting several in situ tests for measurement of various parameters that influence corrosion. Entry of the water was the major cause of corrosion in the building. The analysis of the test results based on the investigations is presented in this paper.

\section{Visual inspection}

The moisture content, $\mathrm{pH}$ value, oxygen level, depth of carbonation, chloride content, relative humidity $(\mathrm{RH})$, exposure conditions, quality of concrete and cover to the reinforcement are the major factors that influence corrosion.

Concrete, which is porous enough to allow water and the carbon dioxide $\left(\mathrm{CO}_{2}\right)$ present in the air, may induce carbonation in concrete. Carbon dioxide reacts with calcium hydroxide $(\mathrm{Ca}$ $\left.(\mathrm{OH})_{2}\right)$ in the cement paste to form calcium carbonate $\left(\mathrm{CaCO}_{3}\right)$ and lower the $\mathrm{pH}$. The movement of water through concrete carries the calcium salts and produces white patches at the concrete surface. A number of patches were seen on the surface of concrete in the building, which indicated water penetration.

The product of corrosion occupied much greater volume than the parent metal. The increase in volume exerted considerable bursting pressure on the surrounding concrete, resulting in cracking. Cracks in the concrete surface were noticed parallel to the reinforcement, which was a visible indication of corrosion of steel bars. A layer of ferric oxide on the reinforcement surface was observed, and the colour of the product was found to be brown, which indicated rusting of the steel surface. When the cover concrete starts spalling, there was a reduction in the bond between concrete and steel. It was noticed in many locations in the structural members. During the process of corrosion, reduction in the size of bars occurs, which may have resulted in snapping of the bars. The latter was noticed during the investigation. The spalling of the concrete and thinning of bars caused the bars to buckle, thus resulting in the deformation of concrete. The structure investigated was found to be in an unstable condition.

Figure 1 shows the view of unprotected rods that were exposed to the environment in the open terrace and the extent of corrosion in the rebar of the columns. The following were the in situ tests conducted in the identified locations according to the relevant standards. The measured parameters were very useful in assessing the condition of the existing structure.

Visual inspection is one of the most versatile and powerful methods, and it is the first step in the evaluation of any deteriorated concrete structure. Visual inspection can provide a set of information that may be useful in identifying the cause of observed distress.

During the visual examination, it was found that most of the damages were local and some defects were classified as global. Therefore, extensive investigation were carried out to determine the residual material strength, so that member strength could be predicted to check the global stability of the structure. Table 1 gives the details of the observations made during the investigation. 


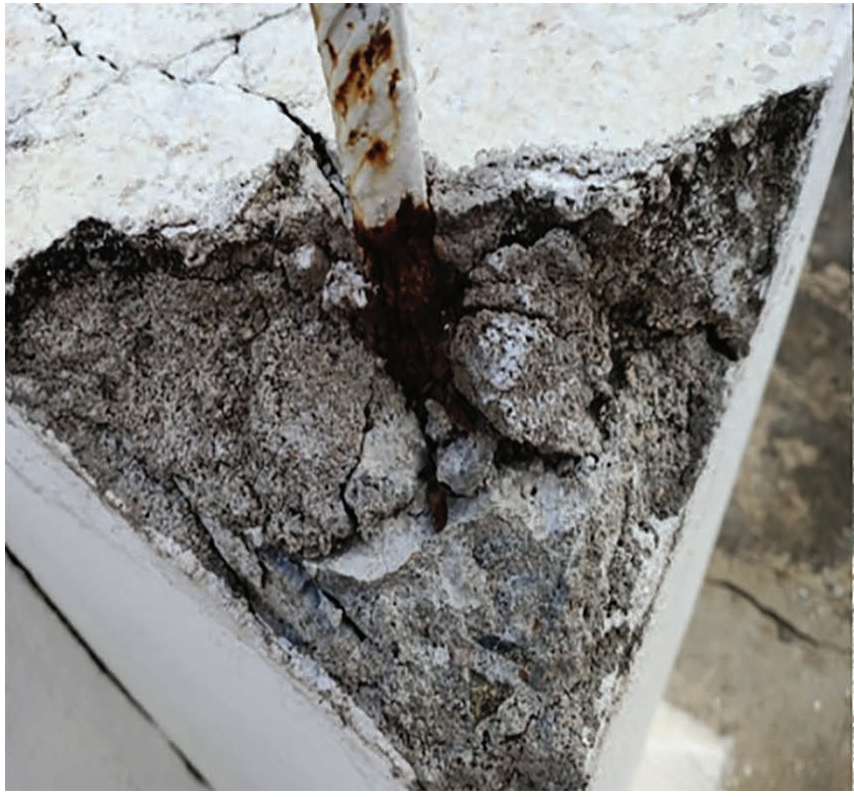

(a)

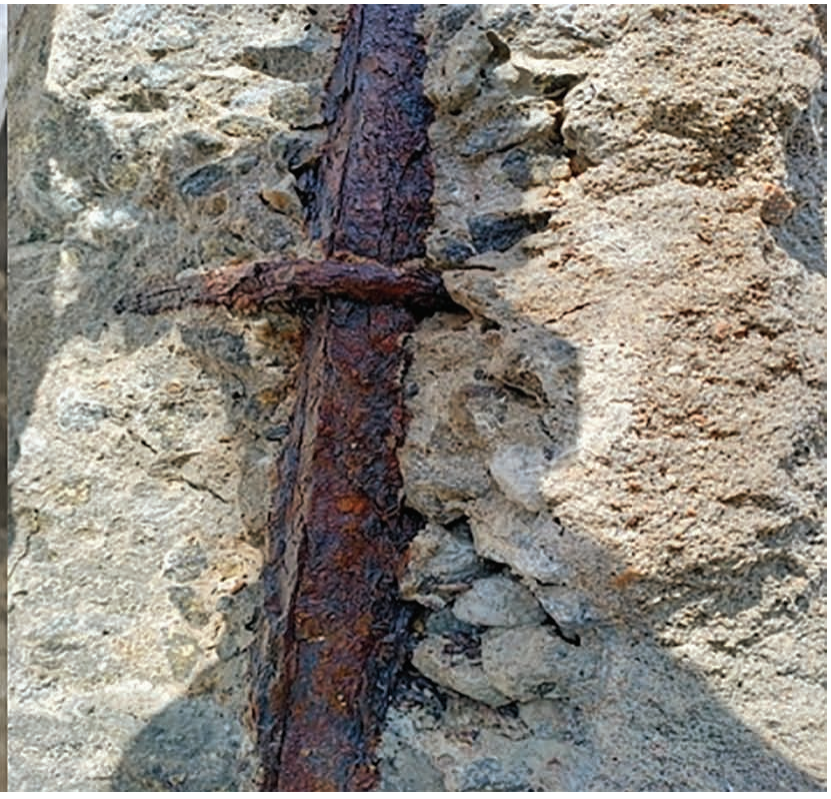

(b)

Figure 1. (a) Unprotected rebar; (b) corrosion of rebar

Table 1. Damage details of the building

\begin{tabular}{|c|c|c|}
\hline Description of defect & Element ID & Remarks \\
\hline Excess deflection & $\begin{array}{l}\text { GF-B1-B13 } \\
\text { GF-B36-B44 }\end{array}$ & Deflected profile of the corroded beam was recorded \\
\hline Spalling of concrete & $\begin{array}{l}\text { CA1, CA3, CA13, CA14, CB14, CC14, } \\
\text { CD14, CC5, CB6 }\end{array}$ & $\begin{array}{l}\text { Damage of cover concrete due to the loss of bond between concrete } \\
\text { and steel was observed }\end{array}$ \\
\hline Cracks & $\begin{array}{l}\text { GF-B1-B13 } \\
\text { GF-B36-B44 }\end{array}$ & $\begin{array}{l}\text { Flexural cracks in the beam (steel corrosion/lack of bond strength in } \\
\text { concrete) were observed }\end{array}$ \\
\hline Rust stains & $\begin{array}{l}\text { CA1, CA3, CA13, CA14, CB14, CC14, } \\
\text { CD14, CC5, CB6 }\end{array}$ & $\begin{array}{l}\text { Colour change in the columns indicating ferrous oxide on surface was } \\
\text { recorded }\end{array}$ \\
\hline Buckling of bars & $\begin{array}{l}\text { CA1, CA3, CA13, CA14, CB14, CC14, } \\
\text { CD14, CC5, CB6 }\end{array}$ & Buckling of corroded bars in columns were noticed \\
\hline Seepage of water & - & Seepage of rainwater and waste water entry into the joints were noticed \\
\hline
\end{tabular}

Figure 2 shows the classification based on three levels of assessment - namely

- global damage state of the building and assessment

- structural component damage assessment

- material damage assessment.

\section{Field investigation (in situ test)}

The following investigations were carried out to examine the corrosion risk and the residual strength of concrete in beams and columns.

\subsection{Rebar and cover meter survey}

Providing adequate cover thickness is necessary to control and delay corrosion. Cracks in concrete, cover thickness and concrete quality are the three major and interrelated parameters influencing the corrosion of steel. Cover is an important factor that preserves the electrochemical stability of steel in concrete. A cover meter survey is useful in determining the actual cover provided in structural elements where damage has occurred. It is also useful in confirming the location of bars. All cover meters work on the basis of the electromagnetic interaction between the search head, which is moved over the surface of the concrete, and the embedded steel rebar. Mortar plaster should to be removed before conducting this test on structural members. Table 2 gives the cover depth values of the structural elements measured using a cover meter.

From Table 2, it can be seen that the cover provided is not adequate as per the recommendation of IS 456:2000 (BIS, 2000). Figure 3 shows the location used for measuring the cover thickness and rebar position using the cover meter.

\subsection{Rebound hammer test}

This test is conducted to assess the condition of the cover concrete. This test is conducted on the identified locations by dividing the members into well-defined grid points. 


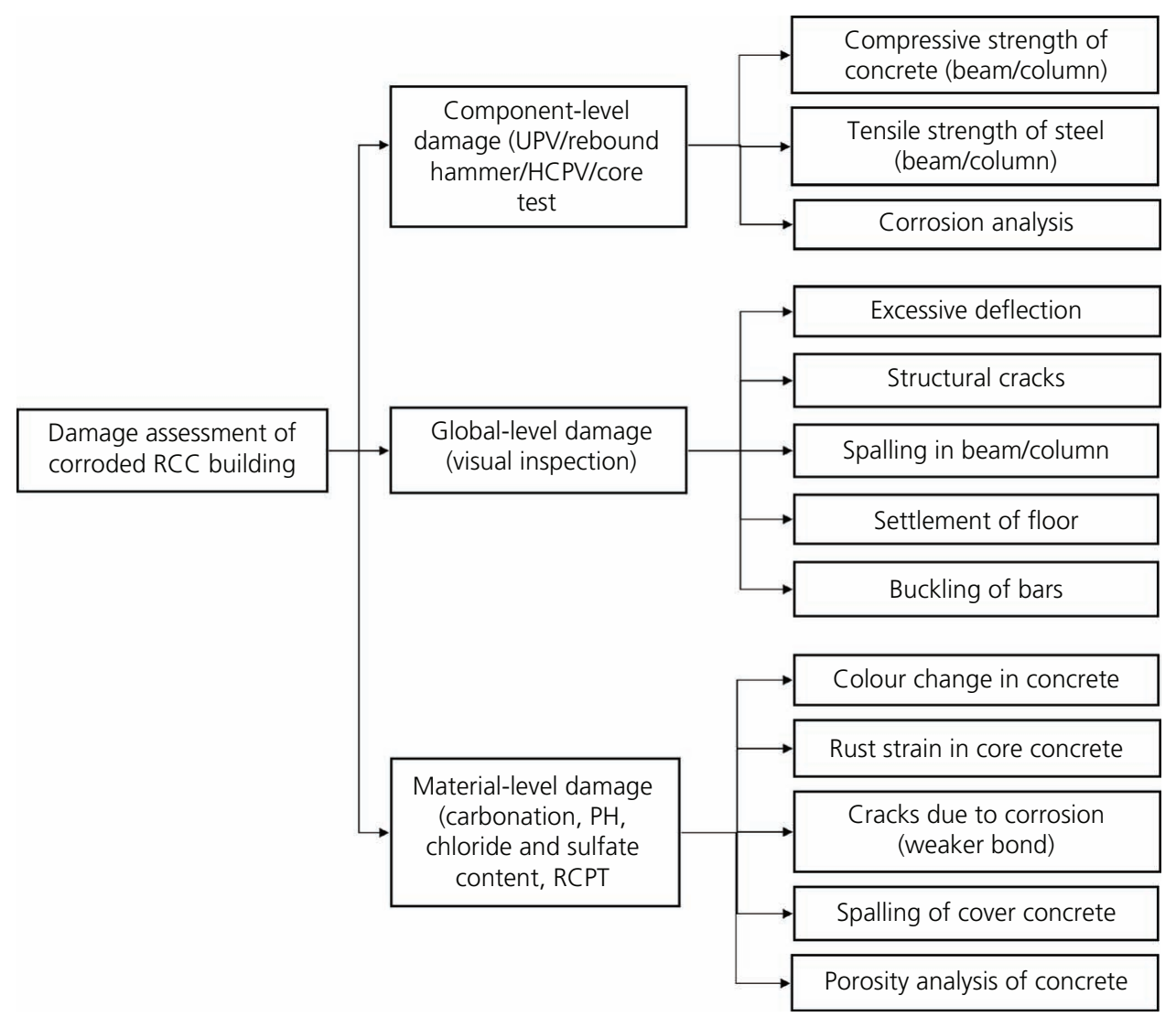

Figure 2. Damage assessment at different stages. HCPV, half-cell potential value; RCC, reinforced cement concrete; RCPT, rapid chloride permeability test; UPV, ultrasonic pulse velocity

Table 2. Details of cover meter readings at specified locations

\begin{tabular}{|lcccc|} 
Number & Location type & Cover: $\mathbf{m m}$ & Remarks & Cover requirement as per IS 456:2000 (moderate exposure): mm \\
\hline 1 & Column GF-CA1 & 22 & Not adequate & 40 \\
2 & Column GF-CA3 & 23 & Not adequate & 40 \\
3 & Column GF-CB6 & 17 & Not adequate & 40 \\
4 & Beam GF-B1 & 19 & Not adequate & 30 \\
5 & Beam RL-B5 & 23 & Not adequate & 30
\end{tabular}

The principle of this test is indirectly measuring the surface hardness of concrete and correlating it with the strength. It is achieved by activating a spring-loaded mass with a given energy and measuring the rebound of a rider on a graduated scale. The relative compressive strength obtained based on the rebound number obtained is to be correlated with the cube compressive strength of concrete. This test was mainly carried out to assess the relative compressive strength of concrete as per IS 13311 (Part 2):1992 (BIS, 1992a). The measured value is known as the rebound number. A concrete with low strength and low stiffness will absorb more energy and give a low rebound value. The details of the locations of columns and beams with the corresponding relative compressive strength are given in Table 3.
According to Monteiro et al., (2009), more experimental field studies, involving a large number of cores and rebound hammer tests, shall be carried out to evaluate the reliability of the strength predictions following EN 13791. This may be helpful in increasing the confidence level for decision making on strength test results.

Monteiro et al., (2009) pointed out that a minimum of 18 samples are required to confirm the variation in test results as per EN 13791. In the present investigation, based on the above said results, the coefficient of variation is found to be 6.56 .

Also, the corresponding compressive strength from the core test result was $15.6 \mathrm{MPa}$. Therefore, the difference between the 
Forensic Engineering

Volume 174 Issue 4
Condition assessment and analysis of a reinforced concrete building in India: a case study

Anand, Andrushia, Paul and Arulraj

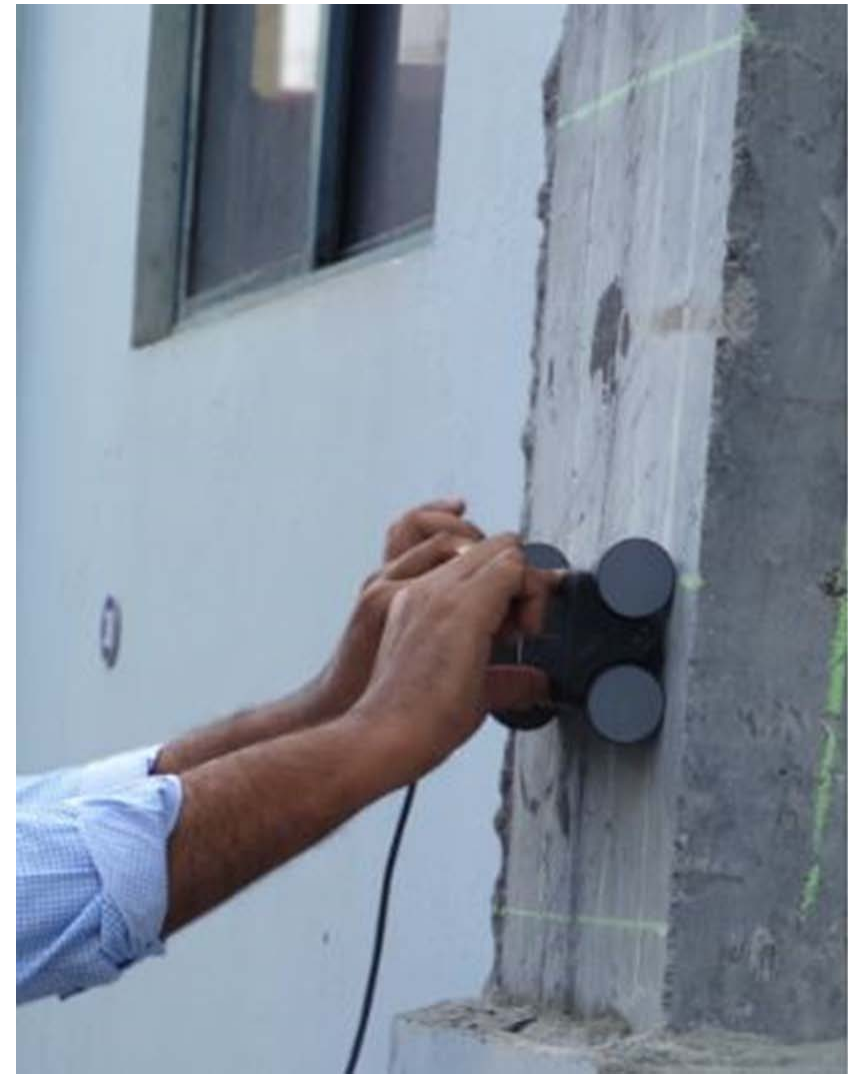

Figure 3. Rebar and cover survey in the field

compressive strengths of the core test and rebound hammer test was $1.65 \mathrm{MPa}$. Also, the percentage variation between the core compressive strength and rebound hammer test was $9.51 \%$. However, for the strength assessment and formulation of the repair strategy, core strength was considered.

The test results indicated that the rebound number ranged between 20 and 30. Control cubes were cast with different mix proportions to correlate the core compressive strength and relative compressive strength obtained from the rebound hammer test. Core samples were extracted from the same locations in the columns and beams in which the rebound hammer test was conducted.

Table 3. Details of the rebound hammer test at specified locations

\begin{tabular}{llcc} 
Number & Location & $\begin{array}{c}\text { Number of } \\
\text { rebound } \\
\text { points }\end{array}$ & $\begin{array}{c}\text { Average relative } \\
\text { compressive } \\
\text { strength: N/mm }\end{array}$ \\
\hline 1 & Column GF-CA1 & 12 & 16.50 \\
2 & Column GF-CA3 & 16 & 16.70 \\
3 & Column GF-CB6 & 16 & 15.20 \\
4 & Column GF-CA13 & 20 & 18.90 \\
5 & Column GF-CA14 & 12 & 18.20 \\
6 & Beam GF-B1 & 16 & 20.90 \\
7 & Beam GF-B5 & 16 & 18.50 \\
8 & Beam GF-B11 & 16 & 19.40 \\
\hline
\end{tabular}

A significant difference was observed from the core compressive strength and relative compressive strength as compared with the strength expected for control cubes of M25 concrete. It was observed that the core samples exhibited a reduction in compressive strength of $35-45 \%$ as compared with compressive strength of control cubes. Figure 4 gives the compressive strengths of core specimens, relative compressive strengths assessed from the rebound hammer test and compressive strength of the control cube specimen.

\subsection{Ultrasonic pulse velocity test}

It is a non-destructive test method used to assess the homogeneity and integrity of concrete. Due to its simplicity, an ultrasonic pulse velocity (UPV) test was carried out on the building affected by corrosion.

The higher the density, elastic modulus and strength of concrete, the higher is the velocity. Locations that have velocities lower than $3.0-3.5 \mathrm{~km} / \mathrm{s}$ are identified as weak locations and may possess voids, cracks and so on (CPWD, 2002). In this type of investigation, pulse velocity values are used primarily to identify the weak regions of concrete to assess the present condition.

The velocity values can also be combined with the rebound number to make a more realistic assessment of the condition of surface concrete. For example, a low velocity and a low rebound number indicate a very weak surface concrete. A UPV test consists of measuring the travel time, $T$, of an ultrasonic pulse of $50-54 \mathrm{kHz}$, produced by an electroacoustical transducer, held in contact with one surface of the concrete member under test and receiving the same by a similar transducer in contact with the surface at the other end. Table 4 gives the guidelines for predicting the quality of concrete based on UPV results (IS 13311 (Part 1):1992 (BIS, 1992b)).

Table 5 shows the results of the UPV values based on the tests conducted in the specified locations.

The test results show moderate UPV values, and hence, according to Table 4, the concrete quality can be considered

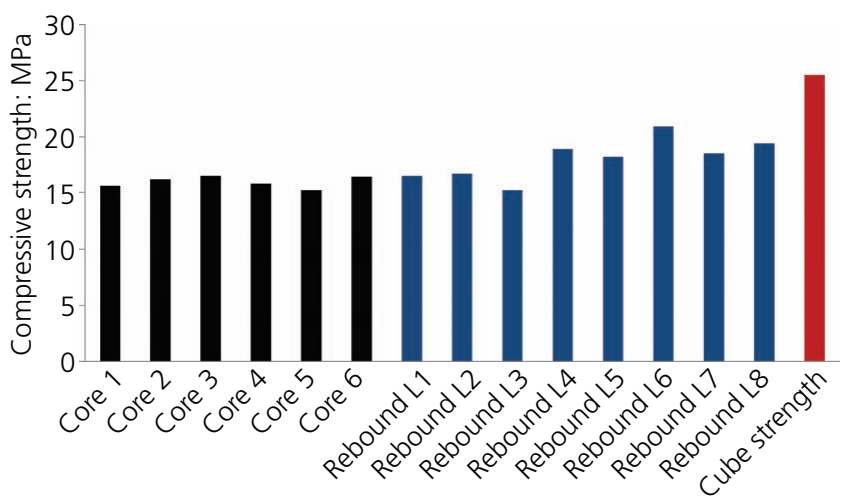

Figure 4. Compressive strength of samples (core/rebound/cube) 
Forensic Engineering

Volume 174 Issue 4
Condition assessment and analysis of a reinforced concrete building in India: a

case study

Anand, Andrushia, Paul and Arulraj
Table 4. General guidelines for the prediction of concrete quality based on UPV

\begin{tabular}{|ccc|}
\hline Number & Pulse velocity: $\mathbf{k m} / \mathbf{s}$ & Concrete quality \\
\hline 1 & $>4.0$ & Excellent \\
2 & $3.5-4.5$ & Good \\
3 & $3.0-3.5$ & Medium \\
4 & $<3.0$ & Doubtful \\
\hline
\end{tabular}

satisfactory. Researchers have found multiple relationship models of the compressive strength of concrete and velocity in the concrete (Huang et al., 2011; Leslie and Cheesman, 1949). Figure 5 shows the field investigation on UPV and rebound hammer. Figure 6 gives the UPV values of the control cube specimens and field samples. A UPV test was performed on the same locations where the rebound hammer test was conducted.

\subsection{HCP survey}

Corrosion being an electrochemical phenomenon, the electrode potential of steel rebar with reference to a standard electrode undergoes changes depending on corrosion activity. A systematic survey on well-defined grid points gives useful information on the presence or probability of corrosion activity.

The advantage of HCP measurements is that these indicate corroding rebars not only in the most external layers of reinforcement facing the reference electrode but also in greater depths (Elsener, 2003). However, it should be noted that the HCP is influenced by the concrete cover, chloride content, compressive strength and moisture content (Yodsudjai and Pattarakittam, 2017).

HCP measurement has been recommended as a non-destructive method for assessing the probability of corrosion of reinforcing

Table 5. Details of the UPV test at specified locations

\begin{tabular}{|c|c|c|c|c|c|c|}
\hline Number & Location & $\begin{array}{c}\text { Number of UPV } \\
\text { points }\end{array}$ & $\begin{array}{l}\text { Maximum } \\
\text { UPV: } \mathrm{km} / \mathrm{s}\end{array}$ & $\begin{array}{l}\text { Minimum } \\
\text { UPV: km/s }\end{array}$ & $\begin{array}{l}\text { Average } \\
\text { UPV: } \mathrm{km} / \mathrm{s}\end{array}$ & Remarks \\
\hline 1 & Column GF-CA1 & 20 & 3.70 & 2.95 & 3.33 & Concrete quality is satisfactory \\
\hline 2 & Column GF-CA3 & 20 & 3.82 & 3.00 & 3.41 & Concrete quality is satisfactory \\
\hline 3 & Column GF-CB6 & 20 & 3.92 & 2.88 & 3.40 & Concrete quality is satisfactory \\
\hline 4 & Beam GF-B1 & 15 & 3.84 & 2.92 & 3.38 & Concrete quality is satisfactory \\
\hline 5 & Beam GF-B5 & 15 & 4.02 & 2.65 & 3.35 & Concrete quality is satisfactory \\
\hline 6 & Beam GF-B11 & 15 & 3.65 & 3.42 & 3.53 & Concrete quality is satisfactory \\
\hline 7 & Column GF-CC5 & 20 & 3.89 & 2.68 & 3.28 & Concrete quality is satisfactory \\
\hline 8 & Column GF-CC11 & 20 & 3.81 & 2.58 & 3.19 & Concrete quality is satisfactory \\
\hline 9 & Column GF-CD11 & 20 & 3.88 & 3.28 & 3.38 & Concrete quality is satisfactory \\
\hline
\end{tabular}

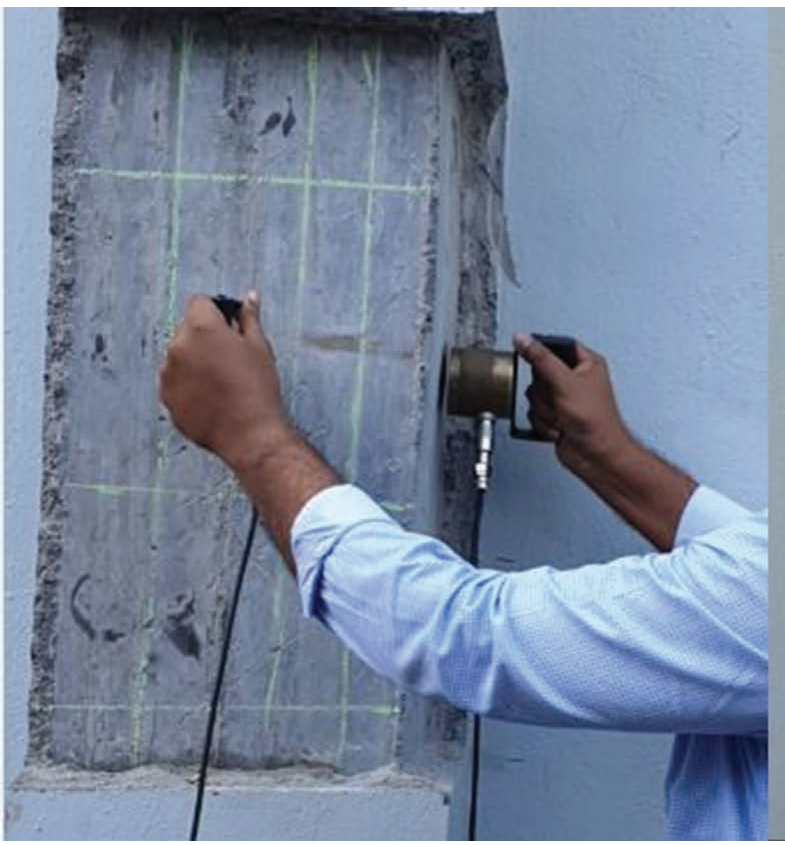

(a)

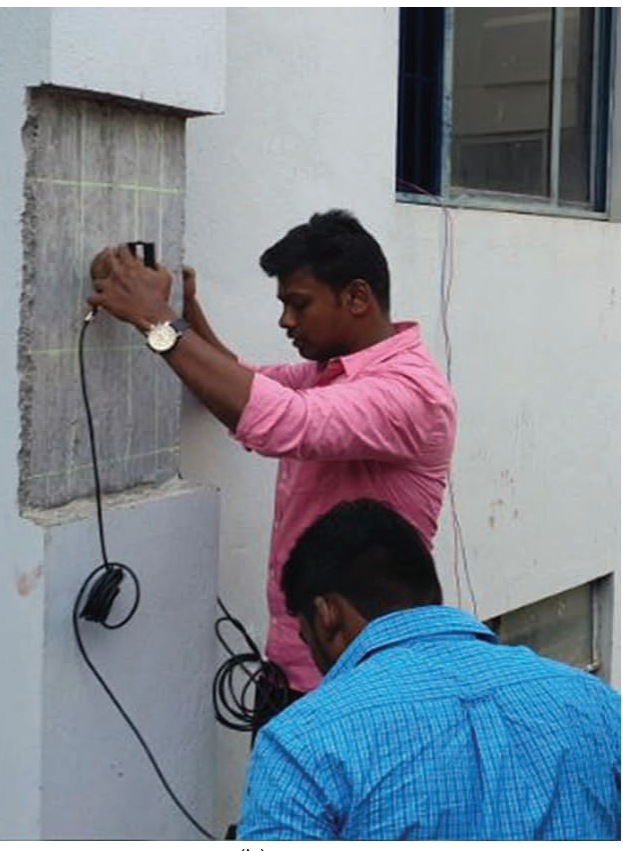

(b)

Figure 5. Field test (a) UPV test - CA1; b) UPV test - CD11 
Condition assessment and analysis of a reinforced concrete building in India: a case study

Anand, Andrushia, Paul and Arulraj

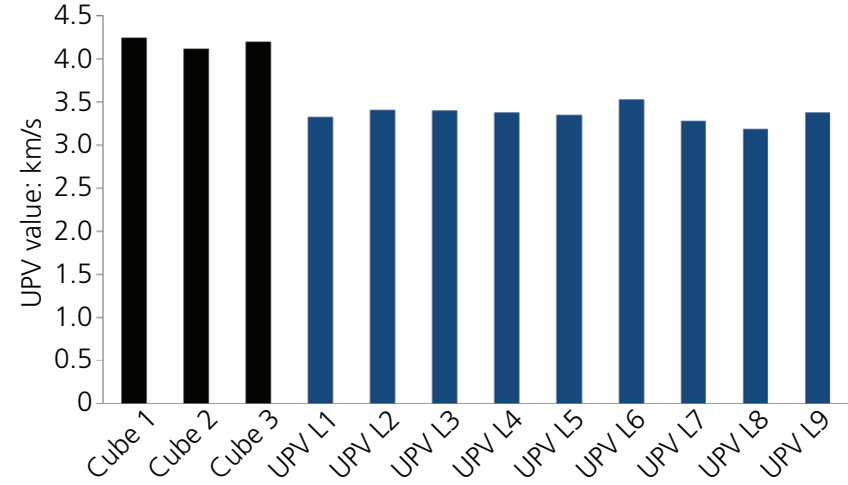

Figure 6. UPV values of the cube and field samples

steel bar before the damage is evident on the surface of the concrete structure. HCP measurement is currently well known and is standardised in ASTM C 876 (ASTM, 2015).

The common standard electrodes are either copper-copper sulfate or silver-silver chloride electrodes. The measurement consists of giving an electrical connection to the rebar and observing the voltage difference between the rebar and a reference electrode in contact with the concrete surface. A simple field testing is carried out with an HCP corrosion analyser, as shown in Figure 7. The general guidelines for identifying the probability of corrosion

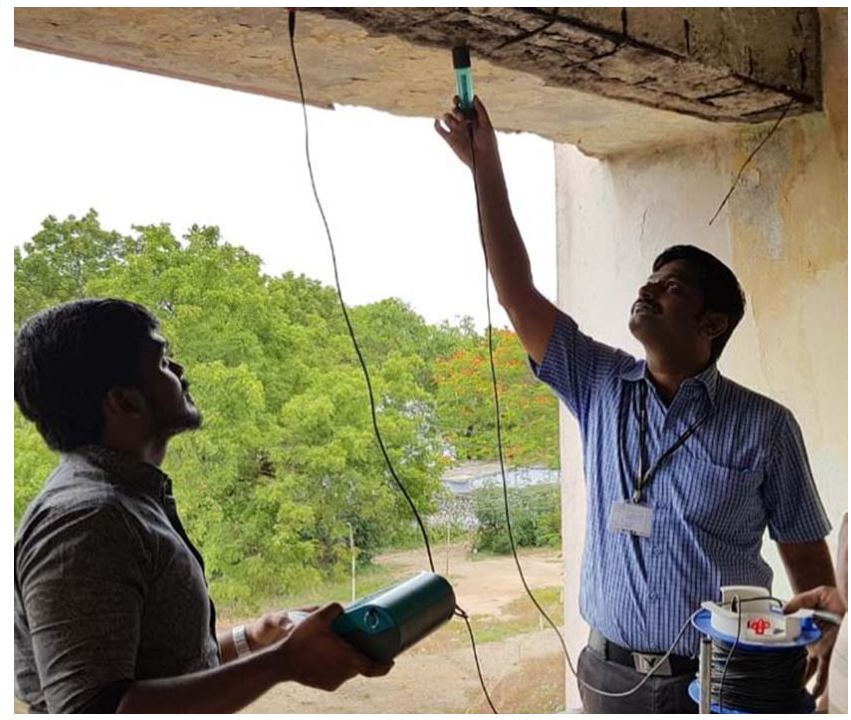

Figure 7. HCP survey in the field based on HCP values as suggested in ASTM C 876 are given in Table 6.

A survey on well-defined grid points gives useful information on the presence or probability of corrosion activity. The electrode used for the present investigation is a copper-copper sulfate electrode. Generally, the voltage potential becomes more and more negative as the corrosion becomes more and more active. However, less negative potential values may also indicate the presence of corrosion activity. Figure 8 shows the HCP values measured at different locations.

Yodsudjai and Pattarakittam (2017) reported that the values of HCP decreased with the increase in concrete cover, chloride content and moisture content.

Table 7 gives the details of rebars measured at specified locations of a structural member.

The table value indicates the diameter measured from the sample rebar taken from the site. A decrease in the diameter is observed. This shows that the corrosion progression is active in the structural members. The test results show a reduction in the yield strength and mass loss of the rebars. Otieno et al. (2019) confirmed that concrete with blended cement requires a higher extent of steel corrosion to initiate cover cracking than concrete with Portland cement.

The reduced yield strength was measured based on the test conducted in the laboratory using the sample rebar collected from the field during inspection. The reduced yield strength was due to the effect of corrosion. Xiong et al. (2017) confirmed that nominal yield strength, nominal ultimate strength and elongation are affected significantly due to the effect of corrosion.

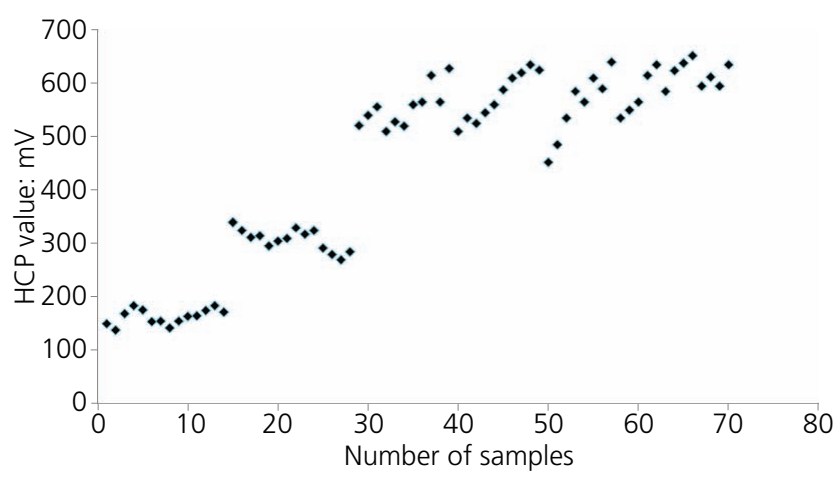

Figure 8. HCP survey values of samples

Table 6. Guidelines of corrosion risk by HCP

\begin{tabular}{|llcl}
\hline Number & \multicolumn{1}{c}{ HCP } & Corrosion potential: \% & \multicolumn{1}{c}{ Remarks } \\
\hline 1 & More negative than $-35 \mathrm{~V}$ & $>90$ & Rebar corrosion is occurring at the time of measurement \\
2 & -200 to $-35 \mathrm{~V}$ & - & Corrosion of rebar is uncertain \\
3 & More positive than $-20 \mathrm{~V}$ & $<10$ & Rebar corrosion is not occurring at the time of measurement
\end{tabular}


Table 7. Details of rebars

\begin{tabular}{|c|c|c|c|c|c|c|}
\hline Number & Location & $\begin{array}{l}\text { Actual diameter } \\
\text { of rebars: } \mathrm{mm}\end{array}$ & $\begin{array}{l}\text { Average diameter of the bar in } \\
\text { corroded portion: } \mathrm{mm}\end{array}$ & $\begin{array}{l}\text { Mass } \\
\text { loss: } \%\end{array}$ & $\begin{array}{l}\text { Yield strength of } \\
\text { rebar: } \mathrm{MPa}\end{array}$ & Remarks \\
\hline 1 & Column GF-CA1 & 16 & 11.60 & 14 & 255 & $\begin{array}{l}\text { Actual yield strength of } \\
\text { rebar is } 500 \mathrm{MPa}\end{array}$ \\
\hline 2 & Column GF-CA3 & 16 & 11.85 & 12 & 281 & $\begin{array}{l}\text { Actual yield strength of } \\
\text { rebar is } 500 \mathrm{MPa}\end{array}$ \\
\hline 3 & Column GF-CB6 & 12 & 9.60 & 13 & 292 & $\begin{array}{l}\text { Actual yield strength of } \\
\text { rebar is } 500 \mathrm{MPa}\end{array}$ \\
\hline
\end{tabular}

Table 8. Half-cell potential values

\begin{tabular}{lll} 
Location & \multicolumn{1}{c}{ HCP readings: $\mathbf{m V}$} & \multicolumn{1}{c}{$\begin{array}{c}\text { Remarks (probability of } \\
\text { corrosion being active) }\end{array}$} \\
\hline Column GF-CA1 & $-624,-638,-652,-595,-612,-595,-635,-640,-635,-550,-565,-615,-635,-58590 \%$ corrosion \\
Column GF-CA3 & $-452,-485,-535,-585,-565,-610,-590,-545,-560,-588,-610,-620,-635,-62590 \%$ corrosion \\
Column RL-CB6 & $-565,-615,-565,-628,-510,-535,-525,-521,-540,-556,-510,-528,-520,-56090 \%$ corrosion \\
Beam GF-B34 & $-330,-318,-325,-292,-280,-270,-285,-340,-325,-312,-315,-296,-305,-310$ Uncertain \\
Beam GF-B43 & $-142,-155,-164,-165,-175,-184,-172,-150,-138,-169,-184,-176,-154,-15590 \%$ no corrosion
\end{tabular}

The corrosion potential values are given in Table 8 .

As per the investigation, the corrosion potential (probability of corrosion being active) in most of the columns were found to be in the range of $90 \%$.

\subsection{Core samples and testing}

As rebound hammer and UPV tests produce indirect proof of the quality of concrete, more accurate assessment can be made by core sample testing. The core samples were taken out from the specified locations, and the following investigations were carried out.

Eight core samples were taken from the identified locations, so that these can be a direct evidence for examining the condition of concrete. Locations were identified between the reinforcement bars with the aid of a rebar locator. The sizes of the core samples were $56 \mathrm{~mm}$ diameter and $200 \mathrm{~mm}$ length. Tests were carried out as per IS 516:2006 (BIS, 2006). Appropriate correction factors were applied to determine the core compressive strength. The combination of rebound, UPV test and core test results can provide precise assessment of the condition of concrete. Table 9 gives the details of the core samples and their equivalent cube compressive strength.
The following are the investigations carried out to examine the material characteristics in beams and columns.

\subsection{Chloride and sulfate content}

Chloride attack is the primary cause of corrosion of concrete structures located in a marine environment. Therefore, concrete structures in such an environment will be susceptible to corrosionrelated problems. Water-soluble chloride and sulfate ions are of importance from corrosion and concrete durability points of view, respectively. Chloride and sulfate contents are determined and compared with limiting values specified for concrete as per IS 456:2000. The $\mathrm{pH}$ value is also determined to predict the alkalinity of concrete. The test results are given in Table 10 .

From the table, it is found that the sulfate and chlorides are within the permissible limit as per IS 456:2000. However, the $\mathrm{pH}$ value is not within the limits.

\subsection{Rapid chloride penetration test}

Core samples of size $100 \times 200 \mathrm{~mm}$ taken from the identified locations were used to check the chloride ion penetration level in the concrete. The rapid chloride permeability test (RCPT) was used to

Table 9. Details of core samples and their equivalent cube compressive strength

\begin{tabular}{|c|c|c|c|c|c|c|}
\hline Number & $\begin{array}{l}\text { Location of the } \\
\text { core sample }\end{array}$ & $\begin{array}{l}\text { Diameter of the } \\
\text { core sample: } \mathrm{mm}\end{array}$ & $\begin{array}{l}\text { Length of the } \\
\text { core sample: } \mathrm{mm}\end{array}$ & $\begin{array}{l}\text { Carbonation } \\
\text { depth: } \mathrm{mm}\end{array}$ & $\begin{array}{l}\text { Cube compressive } \\
\text { strength } \\
\text { (equivalent): } \mathrm{MPa}\end{array}$ & $\begin{array}{c}\text { Average cube } \\
\text { compressive } \\
\text { strength: } \mathrm{MPa}\end{array}$ \\
\hline 1 & Column GF-CA1 & 56 & 140 & 60 & 15.6 & \\
\hline 2 & Column GF-CA3 & 56 & 140 & 62 & 16.2 & \\
\hline 3 & Column GF-CB6 & 56 & 140 & 55 & 16.5 & 15.95 \\
\hline 4 & Column GF-CB14 & 56 & 140 & 55 & 15.8 & \\
\hline 5 & Column GF-CC11 & 56 & 140 & 58 & 15.2 & \\
\hline 6 & Column GF-CD11 & 56 & 140 & Nil & 16.4 & \\
\hline 7 & Beam GF-B1 & 56 & 140 & Nil & 19.5 & 19 \\
\hline 8 & Beam GF-B5 & 56 & 140 & Nil & 18.5 & \\
\hline
\end{tabular}


Table 10. Chemical test results

$\begin{array}{llccl}\text { Number } & \text { Parameter } & \text { Values } & \text { Permissible limit } & \text { Remarks } \\ 1 & \mathrm{pH} & 9.40-12.25 & 12-13 & \text { Significant reduction in alkalinity confirmed } \\ 2 & \text { Chlorides } & 0.32-0.40 & <0.6 \mathrm{~kg} / \mathrm{m}^{3} & \text { Chloride and sulfate contents are within the permissible limit } \\ 3 & \text { Sulfates } & 85 \mathrm{mg} / \mathrm{l} & <400 \mathrm{mg} / \mathrm{l} & \end{array}$

indicate the durability of concrete; RCPT was the standard test used to determine the ability of concrete to resist chloride ion penetration.

Standardised testing procedures were followed as per ASTM C 1202 (ASTM, 2019). The RCPT was performed by monitoring the amount of electrical current that passes through samples of $50 \mathrm{~mm}$ thickness and $100 \mathrm{~mm}$ diameter in $6 \mathrm{~h}$. This sample is typically cut as a slice of a core or cylinder. A voltage of $60 \mathrm{~V}$ direct current is maintained across the ends of the sample throughout the test. One lead is immersed in a $3.0 \%$ salt (sodium chloride $(\mathrm{NaCl})$ ) solution, and the other in a $0.3 \mathrm{M}$ sodium hydroxide $(\mathrm{NaOH})$ solution. Based on the charge that passes through the sample, a qualitative rating is made to determine the permeability of concrete.

Table 11 gives the estimated level of chloride ion penetration for the sample tested in the laboratory. It is seen from the results that the level of chloride ion penetration is under the low category as per ASTM C 1202, indicating good-quality concrete.

\subsection{Carbonation of embedded steel}

Carbonation of concrete is one of the key factors causing deterioration of RC structures. The carbonation depth is typically used to estimate the concrete service life. Normally, rebars embedded in concrete with an alkaline medium with a higher $\mathrm{pH}$ value will not rust. During the hydration process, cement reacts with water and this chemical reaction between cement and water in the concrete produces calcium hydroxide. This calcium hydroxide is responsible for maintaining a high $\mathrm{pH}$ value.

Protection of the rebar from corrosion is provided by the alkalinity of the concrete, thus making the steel to be under a passive condition. If the amount of available calcium hydroxide is high, the penetration of water into concrete in a small amount will not initiate the corrosion process. Atmospheric carbon dioxide reduces the $\mathrm{pH}$ value of concrete - that is, carbonation - and with the help of moisture and humidity, causes corrosion of the rebar. Carbonation is the effect of carbon dioxide reacting with the alkaline environment in concrete in the presence of moisture, converting calcium hydroxide into calcium carbonate.

Table 11. RCPT values of samples

\begin{tabular}{lcl}
\multicolumn{1}{c}{ Location } & Current: C & Remarks \\
Column GF-CA1 & 1252 & Low \\
Column GF-CD11 & 1230 & Low \\
Column GF-CB6 & 1050 & Low \\
Beam GF-B1 & 955 & Low \\
Beam GF-B34 & 980 & Low
\end{tabular}

The $\mathrm{pH}$ value of the pore water generally ranges between 12 and 13. Due to carbonation process, the $\mathrm{pH}$ can be reduced to less than 8 . Therefore, the passive layer is damaged and corrosion occurs. Elsalamawy et al. (2019) reported that among the most important factors that can greatly affect the carbonation resistance of concrete is the RH of the environment and water/cement (w/c) ratio of the concrete mix.

Carbonation is measured using phenolphthalein, an indicator of the $\mathrm{pH}$ value, and as carbonation reduces the $\mathrm{pH}$ of concrete, the change in colour indicates the extent of carbonation. The test is conducted by drilling a hole on the concrete surface to different depths up to the cover concrete and spraying with phenolphthalein. The colour change is observed. An un-carbonated surface exhibits a pink colour ( $\mathrm{pH}$ greater than 8), while carbonated concrete ( $\mathrm{pH}$ less than 8) exhibits no change in colour. The depth of carbonation is estimated based on the change in the colour profile.

Figure 9 shows a schematic sketch of the process of carbonation in a column.

\section{Porosity analysis using an image- processing method}

The porosity of concrete is an indicator of quality and density. An imaging method was used to assess the porosity of the concrete.

The concrete images were initially converted into binary images, which have either ' 0 ' or ' 1 '. Noise removal filters were applied to the image in order to sharpen the input image. A pixel-wise adaptive Wiener filter was applied through the local
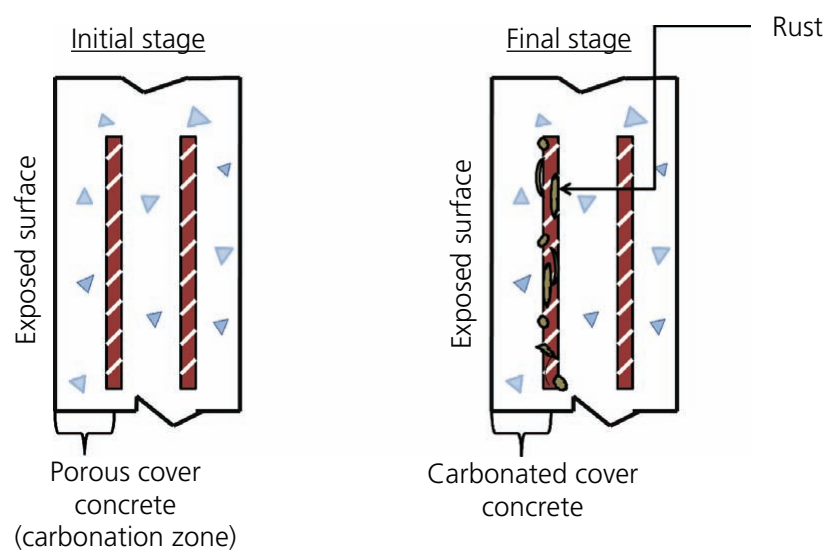

Figure 9. Process of carbonation 
neighbourhood pixels. The local average $(A)$ and variance $(v)$ of each pixel was calculated by using the equations

$$
\text { 1. } A=\frac{1}{X Y} \sum P\left(x_{1}, x_{2}\right)
$$

2. $v=\frac{1}{X Y} \sum P^{2}\left(x_{1}, x_{2}\right)-A^{2}$

where $x$ is the $X$-by- $Y$ local neighbourhood of the pixel $P\left(x_{1}, x_{2}\right)$. Wiener filter coefficients $w\left(x_{1}, x_{2}\right)$ are obtained from Equation 3

3. $w\left(x_{1}, x_{2}\right)=A v+\frac{v^{2}+a^{2}}{v^{2}}\left[P\left(x_{1}, x_{2}\right)-A\right]$

where $a^{2}$ is the noise variance. The Wiener filter uses the mean of the local estimated variances.

In the binary image, ' 0 ' pixels are considered background and ' 1 ' pixels are considered objects. The porosity is found with respect to the boundaries of pores. The area of the each pore is calculated based on the diameter. The total area is the scalar value with respect to the total number of active pixels in the image. Each image has a different pattern of pixel weights (Mahmood et al., 2014). Minimum variations are observed between real-time and image-processing-based calculations. The Matlab software was used for the image analysis.

Figure 10 shows the porosity levels of the control cube samples and the field sample. The first specimen shows the porosity of the control cube sample. A significant difference in porosity is observed between the control cube sample and field samples. The same size of the image was considered for the analysis. Figure 10(a) shows the porosity level of the control cube sample, and Figures 10(b)-10(d) show the porosity levels of field samples. Through the image analysis, the porosity of the cube samples (Figure 10(a)) were found to be less than $4 \%$, whereas in the case of field samples, it was found to be within the range $48-61 \%$.

The measurements show that porosity strongly depends on the surface morphology of the image samples. The image-processing method is a proven method that is useful in predicting the porosity level of concrete with more accuracy.

\section{Deemed to satisfy}

Most of concrete standards worldwide are based on deemed-tosatisfy requirements (ISO 16204:2012 (ISO, 2012)) concerning the durability of concrete structures. These requirements are normally linked to criteria such as maximum w/c ratio, cement type, cover to the reinforcement and crack limitations. The designer recommends limiting values that, if met by the structure, result in the structure being 'deemed to satisfy' the durability requirements. Table 12 gives
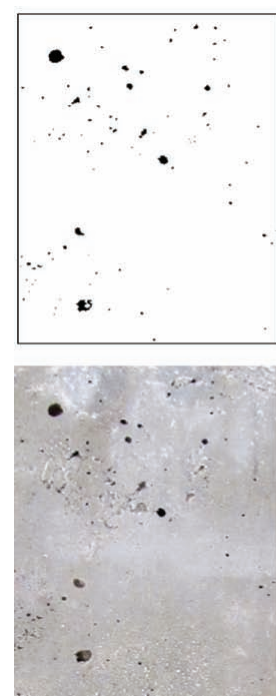

(a)
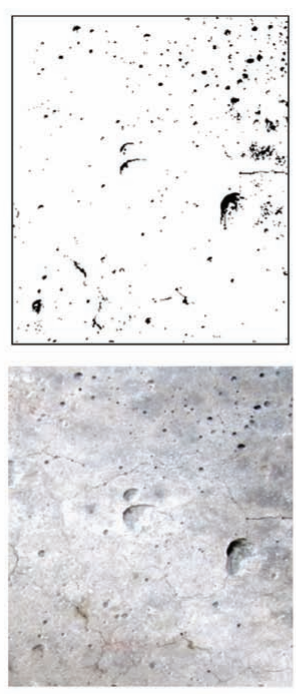

(b)
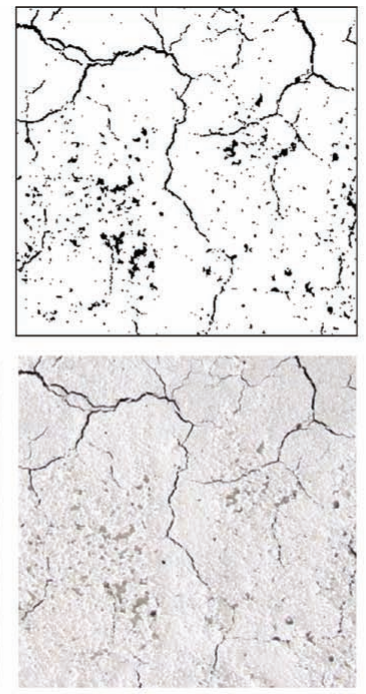

(c)
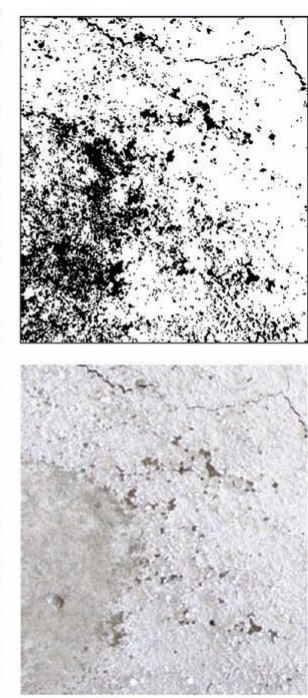

(d)

Figure 10. Porosity analysis (a) Image of control cube; (b) Image of field sample 1; (c) Image of field sample 2; (d) Image of field sample 3

Table 12. Minimum requirements for satisfying the serviceability criteria

\begin{tabular}{|ccccc}
$\begin{array}{c}\text { Exposure } \\
\text { condition }\end{array}$ & $\begin{array}{c}\text { Maximum free } \\
\text { w/c ratio }\end{array}$ & Cement type & $\begin{array}{c}\text { Minimum cement } \\
\text { content: } \mathbf{k g} / \mathbf{m}^{3}\end{array}$ & $\begin{array}{c}\text { Nominal concrete } \\
\text { cover: } \mathbf{m m}\end{array}$ \\
\hline Moderate & 0.5 & Ordinary Portland cement & 300 & 30 \\
\hline
\end{tabular}


the minimum requirements for satisfying the serviceability criteria for the moderate exposure condition based on IS 456:2000.

Based on the investigation and the test results, it was confirmed that the minimum strength requirements and durability criteria for the warehouse were not satisfied as per IS 456:2000. During the investigation, it was found that the grade of concrete was M15 and a much higher degree of porosity was observed. The cover to the concrete was also found to be below the minimum required and not conforming to the standard. As the required limit state criteria were not satisfied, the service life of the structure was expected to be less than the intended 50 years normally required (see Table 13).

The performance-based durability specifications from the deemedto-satisfy approach are found to be more conservative. This allows the designer to select an optimal material composition that will resist the environmental agents threatening the structure and hopefully prolong the period to corrosion initiation. Thus, durability design of RC structures using this deemed-to-satisfy approach offers the designer and material supplier the flexibility in selecting an appropriate choice of materials and mix proportions of concrete (Helland, 2013; Muigai et al., 2012).

\subsection{Desired service life}

The desired service life of the structure needs to be clearly established as part of the design process. The required material and construction quality increases with increased service life. A guideline for typical values provided by ISO 16204:2012 is shown in Table 13. For RC structures, the most relevant categories are common structures and monumental structures, for which the design life is 50 and 100 years, respectively (Alexander et al., 2008).

\subsection{Concrete quality and cover thickness}

The quality of concrete is one parameter that the designer can specify to achieve the desired service life under the exposure conditions, the other parameter being the cover thickness. Improving the material quality means a denser, less permeable concrete that slows the rate of ingress of aggressive chemicals that is, chloride ions or carbon dioxide. A slower rate of transport delays the time of the beginning of corrosion and thus extends the service life of a structure.

Cover thickness is the other parameter specified by the designer to achieve the desired service life. A greater concrete cover means a longer distance for aggressive agents to travel before they can depassivate the reinforcing steel. The required concrete cover and material quality are not unrelated, as a higher concrete quality

Table 13. Deemed-to-satisfy values for carbonating conditions

\begin{tabular}{lcrr} 
& Common structures & \multicolumn{2}{c}{$\begin{array}{c}\text { Monumental } \\
\text { structures }\end{array}$} \\
\cline { 3 - 4 } & & $(1)$ & (2) \\
Service life: years & 50 & 100 & 100 \\
Minimum cover: $m m$ & 30 & 30 & 40
\end{tabular}

may permit a lower concrete cover for similar performance. The balance between material quality and cover thickness is normally determined considering practical and economic considerations.

The actual limiting value must be specified by the designer, but typical minimum cover depths are $30 \mathrm{~mm}$ for a carbonating environment as per ISO 16204:2012. For performance evaluation of corrosion resistance, the cover depth actually achieved during construction was one of the performance criteria, and it was measured using a cover meter.

One of the major causes of carbonation in the investigated warehouse structure is the lower cover thickness not satisfying the requirements of IS 456:2000 based on the exposure condition and the lower strength affecting porosity and the $\mathrm{w} / \mathrm{c}$ ratio. Therefore, the desired service life of the structure will not be satisfied.

\section{Observations and discussion}

Corrosion, a result of chemical or electrochemical actions, is the most common mechanism responsible for deterioration of RC structures; it is mainly governed by chloride ingress and carbonation depth. When chloride ions penetrate into concrete more than the threshold value or when the carbonation depth exceeds the concrete cover, then the corrosion of reinforcement is initiated. If the corrosion is initiated in concrete structures, it progresses to weaken the structure, as the steel section is lost, and reduces the service life of the structures and the rate of corrosion affects the remaining service life of RC structures (Verma et al., 2014).

The diffusion of oxygen is a necessary factor for corrosion inhibition as long as the RC is not placed completely under water even under very high-humidity environmental conditions of as much as 95\% RH (Hussain, 2011a). Severe environments can cause corrosion only if enough amounts of oxygen and moisture are available in the vicinity of the corroding reinforcement bar in concrete. Therefore, it is necessary to understand the combined effect of oxygen and moisture on the corrosion of RC structures.

The corrosion rate is very slow when the concrete is submerged under water as compared with that under normal dry-air conditions. However, the corrosion rate under high-moisture conditions (90-95\% $\mathrm{RH}$ ) can be enough to block the passage of gaseous oxygen (Bulu and Bhattacharjee, 2009; Hurling, 1984; Hussain, 2011a, 2011b, 2011c; Hussain and Ishida, 2010a, 2010b, 2011a, 2011b; Maruya et al., 2003; Raupach, 1996a, 1996b; Shruti and Mukherjee, 2011).

Corrosion of embedded metals in concrete can be greatly reduced by placing crack-free concrete with low permeability and sufficient concrete cover. Low-permeability concrete can be attained by decreasing the $\mathrm{w} / \mathrm{c}$ ratio of the concrete and using alternative cementing materials such as pozzolans or ground granulated blastfurnace slag. In the present investigation, the presence of corrosion is confirmed in the structural elements based on the field investigations and laboratory test results. The occurrence of carbonation is found to be the major cause of corrosion. Also, it is evident from the 
investigation that concrete is porous enough to allow rapid entry of carbon dioxide. It was obvious that concrete with a high w/c ratio was used for the construction. The entry of water through the porous concrete was noticed during the investigation. Therefore, a higher water content, lower cover concrete and concrete with a porous medium were the key factors responsible for the occurrence of carbonation.

Many cracks, including spalling of concrete, were observed in the columns. Corrosion of rebars and reduction in the diameter of rebars were noticed, and these were evident from the HCP test results. The corrosion test results indicate that most of the columns are found to be affected with corrosion and the probability of corroded areas being active is $90 \%$.

The occurrence of corrosion at the warehouse was mainly due to carbonation since the chloride contents in the concrete samples were within the permissible limits prescribed in IS 456:2000. The test results for the core samples also justified the occurrence of carbonation. A significant reduction in the alkalinity of concrete samples was also noticed. Corrosion was noticed in many locations of the column and beam column joints, with loss of reinforcement cross-section. This might be due to the severe leakage of water through pores for a long period.

It was found from the UPV results of columns and beams that the structural concrete was porous. The difference between the average core compressive strength of samples and the relative compressive strength found from the rebound hammer test was found to be marginal. Core test results showed that the target compressive strength that was required for M20 concrete was not attained.

\section{Repair and retrofitting}

\subsection{Modelling and analysis}

The existing structure was modelled to check its stability with the available material and geometrical data. Also, the structure was designed to withstand static load requirements, satisfying the limit state of collapse and serviceability.

The existing building frame consisted of conventional RC beams and columns that were cast monolithically. Vertical loads were considered for the analysis of frame. Analysis was carried out to determine the critical bending moment, shear force and axial load of structural members.

The analysis of the building frame was carried out using the STAAD Pro software package. Beams and columns were modelled with support conditions as rigid. The slab was considered a rigid diaphragm at the respective floor levels. Appropriate loads and their combinations, as per the IS 456:2000 code, were considered.

\subsection{Design check}

Critical axial force, bending moment and shear force values as per the load combination were considered for the design. Tables 14 and 15 give the details of analysis of the building considered for assessment. The axial resistance, moment of resistance and shear resistance were calculated using the geometrical and material data obtained from the field investigation. The results were presented for some of the selected members considered during investigation. Figure 11 shows the locations of the sample points.

The compressive strength of concrete based on core test results $(15.95 \mathrm{MPa})$ and the yield strength of steel based on the sample tested from the field $(255 \mathrm{MPa})$ were considered to determine the reduced axial strength of columns. The effective core area was considered by omitting the cover concrete. The area of steel for the corroded rods was calculated based on the reduced diameter found during the field test. The existing structure was still stable. However, retrofitting was required for some of the beams and columns to restore the strength. Jacketing and wrapping with carbon-fibre-reinforced polymer sheets were recommended for retrofitting.

\subsection{Details of retrofitting}

The fibre wrap technique, also known as a composite fibre system, is a non-intrusive structural strengthening technique that increases the load-carrying capacity (shear, flexural, compressive) and ductility of RC members without causing any destruction or distress to the existing concrete (CPWD, 2002).

This system comprises of pre-cut unidirectional fibre (carbon) wrapped over epoxy primer applied on the prepared surface of the member requiring structural strengthening and surface protection.

Table 14. Analysis details of beams

\begin{tabular}{|c|c|c|c|c|c|c|}
\hline $\begin{array}{l}\text { Beam } \\
\text { number }\end{array}$ & Size: mm & $\begin{array}{l}\text { Maximum moment at } \\
\text { critical section: } \mathrm{kN} \mathrm{m}\end{array}$ & $\begin{array}{l}\text { Moment of } \\
\text { resistance: } \mathrm{kN} \mathrm{m}\end{array}$ & $\begin{array}{l}\text { Maximum shear at } \\
\text { critical section: } k N\end{array}$ & $\begin{array}{c}\text { Shear } \\
\text { resistance: } \\
\text { kN }\end{array}$ & Remarks \\
\hline GF-B1 & $230 \times 300$ & 56.25 & 37.16 & 41.25 & 54.26 & CFRP wrapping is required \\
\hline GF-B5 & $230 \times 450$ & 95.60 & 65.52 & 68.26 & 84.56 & CFRP wrapping is required \\
\hline GF-B28 & $230 \times 380$ & 65.05 & 47.88 & 56.66 & 63.80 & CFRP wrapping is required \\
\hline GF-B11 & $230 \times 300$ & 48.25 & 52.55 & 35.67 & 47.36 & $\begin{array}{l}\text { The section is safe in } \\
\text { bending and shear }\end{array}$ \\
\hline GF-B34 & $230 \times 380$ & 67.44 & 71.66 & 51.22 & 68.15 & $\begin{array}{c}\text { The section is safe in } \\
\text { bending and shear }\end{array}$ \\
\hline
\end{tabular}


Table 15. Analysis details of columns

\begin{tabular}{|c|c|c|c|c|c|c|}
\hline $\begin{array}{l}\text { Column } \\
\text { number }\end{array}$ & $\begin{array}{l}\text { Size } \\
\text { provided: } \\
\mathrm{mm}\end{array}$ & $\begin{array}{l}\text { Axial } \\
\text { load: } \\
\text { kN }\end{array}$ & $\begin{array}{l}\text { Axial load- } \\
\text { carrying } \\
\text { capacity: kN }\end{array}$ & $\begin{array}{l}\text { Reduction in } \\
\text { axial strength: \% }\end{array}$ & $\begin{array}{l}\text { Minimum area of } \\
\text { steel required: } \mathrm{mm}^{2}\end{array}$ & Remarks \\
\hline CA1 & $230 \times 300$ & 305 & 324 & 12.65 & 552 & $\begin{array}{l}\text { The cross-section and area of } \\
\text { reinforcement provided are adequate }\end{array}$ \\
\hline CA3 & $230 \times 380$ & 520 & 432 & 20.37 & 699 & $\begin{array}{l}\text { Minimum reinforcement required/shall } \\
\text { be provided with jacketing }\end{array}$ \\
\hline $\mathrm{CC} 3$ & $380 \times 380$ & 1008 & 738 & 36.58 & 1155 & $\begin{array}{l}\text { Minimum reinforcement } \\
\text { required/CFRP wrapping } \\
\text { reinforcement }\end{array}$ \\
\hline CB6 & $230 \times 450$ & 1136 & 711 & 59.77 & 828 & $\begin{array}{l}\text { Minimum reinforcement } \\
\text { required/CFRP wrapping }\end{array}$ \\
\hline CC5 & $230 \times 380$ & 440 & 432 & 14.81 & 699 & $\begin{array}{l}\text { The cross-section and area of } \\
\text { reinforcement provided are adequate }\end{array}$ \\
\hline
\end{tabular}

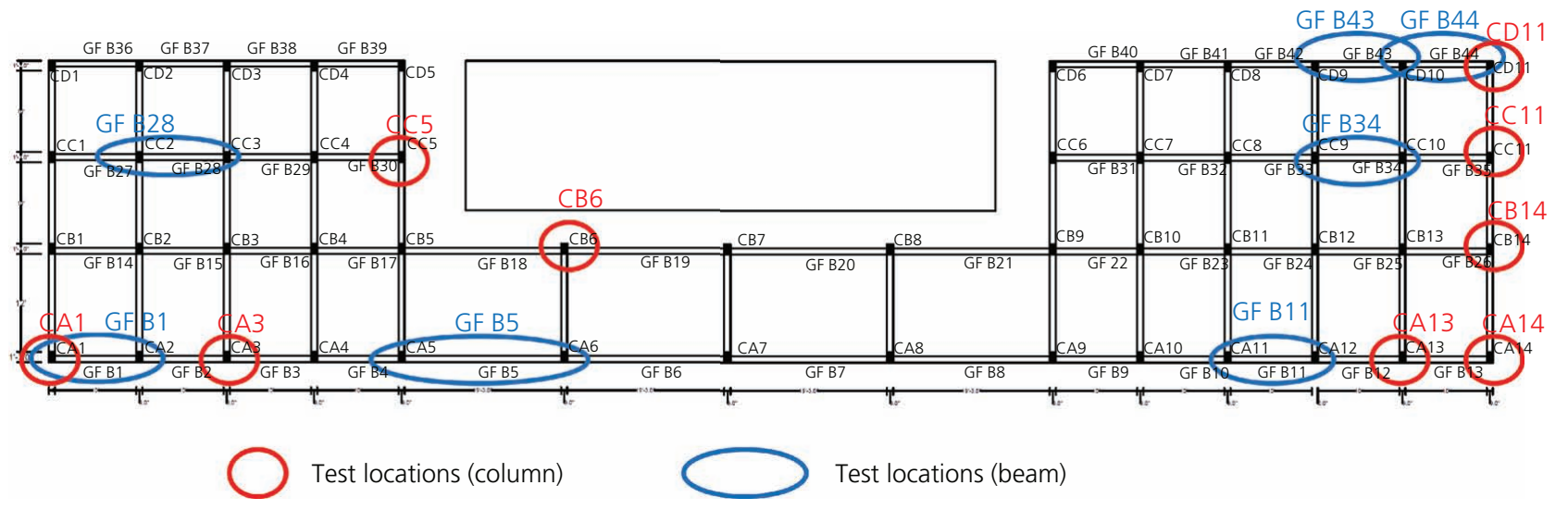

Figure 11. Locations of sample points

Subsequent to its wrapping, it is saturated with epoxy using rollers and stamping brushes manually to remove air bubbles, if any, and left to cure at the ambient temperature. The subsequent layers of unidirectional fibre fabric should be applied after giving the required overlap along the direction of fibres.

The flexural, shear and axial load-carrying capacities of the structural members can be enhanced by appropriate orientation of the primary fibres of the composites. The resulting cured membrane not only strengthens the RC member but also acts as an excellent barrier to corrosive agents, which are detrimental to concrete and the reinforcement. Ingress of water, oxygen and carbon dioxide through the external surface of the concrete member is prevented by the application of a composite jacket. The various steps involved in the strengthening process are cleaning the surface, patching up the surface irregularities, rounding of the corners to a radius of $20 \mathrm{~mm}$, pre-cutting the fabric according to dimensions required, mixing the epoxy by using a high-speed mixer for $5 \mathrm{~min}$, saturating the fabric with epoxy manually or using a mechanical saturator, wrapping the member with the saturated fabric material after priming the surface with epoxy and curing for $24 \mathrm{~h}$ at ambient temperatures including applying cement plaster finish over the outermost layer. A schematic diagram showing the wrapping of a column is shown in Figure 12.
Jayasree et al. (2016) carried out an investigation on the flexural behaviour of corroded RC beams after retrofitting with ferrocement jacketing.

Before the retrofitting work, rusts were removed from the corroded bars. The entire portion was cleaned using a brush. The

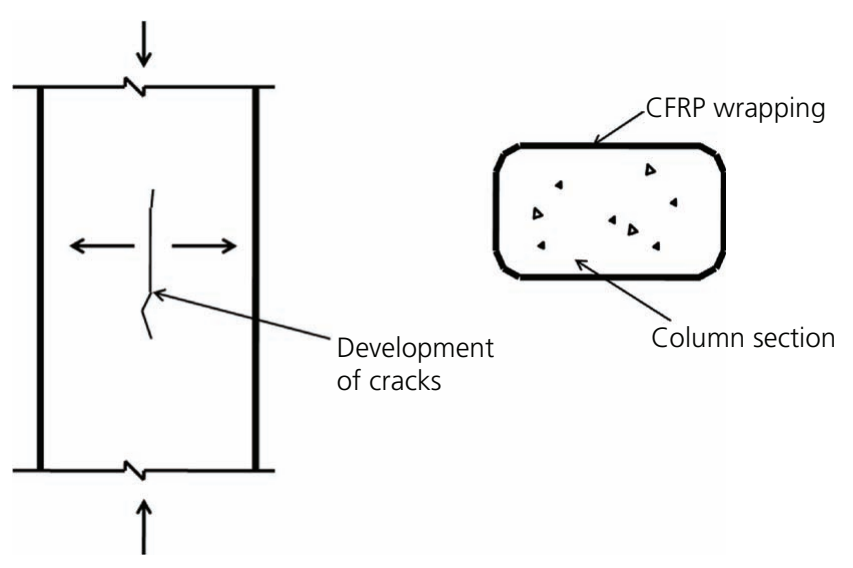

Figure 12. Schematic diagram showing the wrapping of a column 

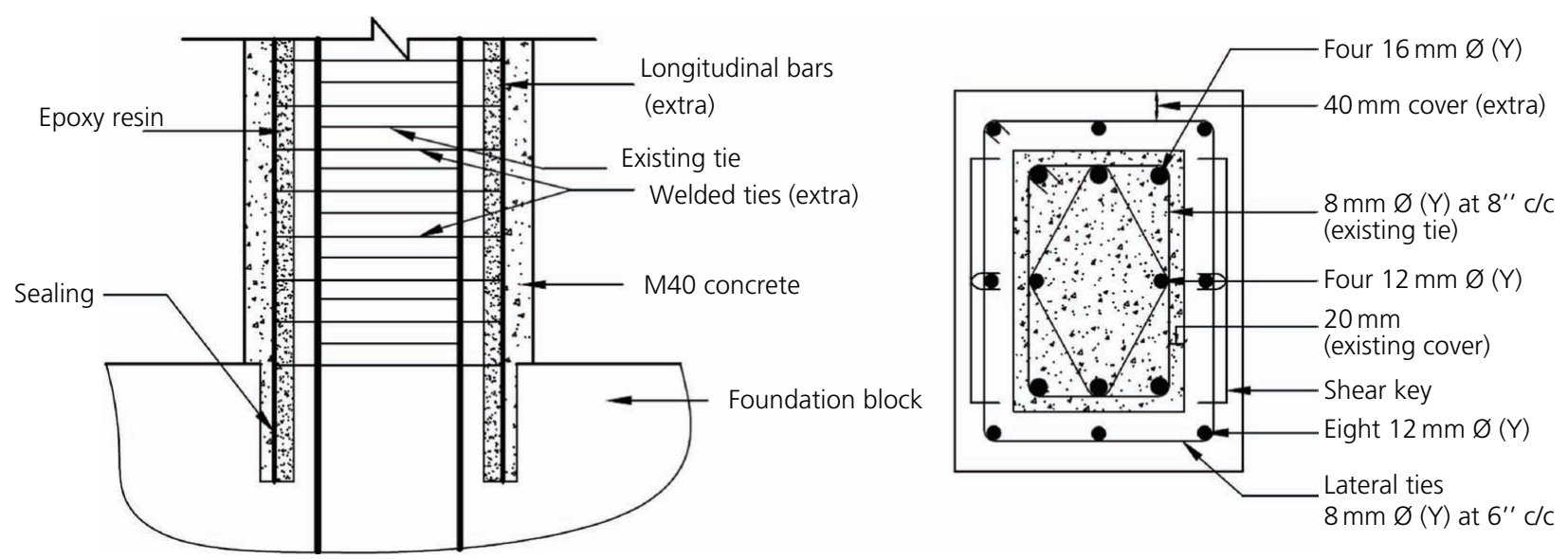

Figure 13. Details of jacketing for column CB6. $1^{\prime \prime}=1 \mathrm{inch}=25.4 \mathrm{~mm}$; $\mathrm{C} / \mathrm{c}$, centre to centre

spalled surface was coated with latex-based polymer. Anticorrosive resisting paint was used to coat the corroded bars. Proper shuttering was used to cover the spalled area, and grouting of micro-concrete was done in all the portions covered with shuttering. A rebound hammer was used to check the rate of gain in strength after 7 days.

Based on the analysis results, it was recommended that the columns should be repaired with suitable jacketing by providing minimum reinforcement to satisfy the requirements of static loads with a load combination of 1.5 times dead and live loads. Also, the identified columns and beams should be retrofitted with carbon-fibre-reinforced plastic wrapping of $450 \mathrm{~g} / \mathrm{m}^{2}$.

The scheme and details of jacketing for column CB6 are shown in Figure 13.

\section{Conclusions and recommendations}

The following are the conclusions drawn from the field and laboratory investigations carried out on the RC building frame.

- The core samples extracted from the identified locations confirmed the existence of high depths of carbonation. The maximum depth of carbonation was found to be $62 \mathrm{~mm}$, and it exceeded the depth of the cover.

- The average compressive strength of core samples extracted from columns was $15.95 \mathrm{MPa}$ and that for beams was $19 \mathrm{MPa}$, which is far below the code requirements of $25 \mathrm{MPa}$ for similar exposure condition.

- The HCP readings confirmed that corrosion was active in most of the ground-floor columns; the corrosion had a probability of $90 \%$ of being active.

- However, chlorides were found to be within permissible limits.

- The nominal cover ranged between 17 and $23 \mathrm{~mm}$ for columns. It was between 19 and $23 \mathrm{~mm}$ for beams. It was found to be inadequate for moderate exposure, which was 40 and $30 \mathrm{~mm}$, respectively.
- Based on the investigation and the test results, it was confirmed that the minimum strength requirements and durability criteria were not satisfied as per IS 456:2000.

- One of the major causes of corrosion in the investigated structure was the lower cover thickness not satisfying the requirements of IS 456:2000 based on the carbonation exposure condition. Therefore, the desired service life of the structure was not satisfied.

- The performance-based service life of structures depends on the limiting requirements such as a cover to the reinforcement, maximum $\mathrm{w} / \mathrm{c}$ ratio, minimum grade of concrete and minimum cement content. Therefore, considering this facts, the actual limiting value must be specified by the designer based on exposure conditions.

\section{Acknowledgement}

Authors of this manuscript would like to thank the management of Karunya University for providing all the facilities with the best infrastructure to carry out this research work.

\section{REFERENCES}

Alexander MG, Ballim Y and Stanish K (2008) A framework for use of durability indexes in performance-based design and specifications for reinforced concrete structures. Materials and Structures 41(5): 921-936, https://doi.org/10.1617/s11527-007-9295-0.

Anterrieu O, Giroux B, Gloaguen E and Carde C (2019) Non-destructive data assimilation as a tool to diagnose corrosion rate in reinforced concrete structures. Journal of Building Engineering 23: 193-206, https://doi.org/10.1016/j.jobe.2019.01.033.

ASTM (2015) C 876-15: Standard test method for corrosion potentials of uncoated reinforcing steel in concrete. ASTM International, West Conshohocken, PA, USA.

ASTM (2019) C 1202-19: Standard test method for electrical indication of concrete's ability to resist chloride ion penetration. ASTM International, West Conshohocken, PA, USA.

BIS (Bureau of Indian Standards) (1992a) IS 13311 (Part 2):1992: Nondestructive testing of concrete - method of test - rebound hammer. BIS, New Delhi, India.

BIS (1992b) IS 13311 (Part 1):1992: Non-destructive testing of concrete method of test - ultrasonic pulse velocity. BIS, New Delhi, India. 
BIS (2000) IS 456:2000: Plain and reinforced concrete - code of practice. BIS, New Delhi, India.

BIS (2006) IS 516:2006: Method of tests for strength of concrete. BIS, New Delhi, India.

Breysse D (ed.) (2012) Non-destructive Assessment of Concrete Structures. Reliability and Limits of Single and Combined Techniques - State-ofthe-art Report of the RILEM Technical Committee 207-INR. Springer, Dordrecht, the Netherlands, vol. 1

Bulu P and Bhattacharjee B (2009) Half-cell potential as an indicator of chloride-induced rebar corrosion initiation in RC. Journal of Materials in Civil Engineering 21(10): 543-552, https://doi.org/10.1061/(asce) 0899-1561(2009)21:10(543.

Cairns J, Gehlen C, Andrade C et al. (2011) Condition Control and Assessment of Reinforced Concrete Structures Exposed to Corrosive Environments. International Federation for Structural Concrete, Lausanne, Switzerland, vol. 59, p. 80.

Conde B, Ramos LF, Oliveira DV, Riveiro B and Solla M (2017) Structural assessment of masonry arch bridges by combination of non-destructive testing techniques and three-dimensional numerical modelling: application to Vilanova bridge. Engineering Structures 148: 621-638, https://doi.org/10.1016/j.engstruct.2017.07.011.

CPWD (Central Public Works Department) (2002) Handbook on Repair and Rehabilitation of RCC Buildings. CPWD, New Delhi, India.

Cui F, Shang H, Zhao TJ, Fan G and Ren G (2017) Mechanical and failure criteria of air-entrained concrete under triaxial compression load after rapid freeze-thaw cycles. Advances in Materials Science and Engineering 2017: article 6786270, https://doi.org/10.1155/2017/6786270.

Elsalamawy M, Mohamed AR and Kamal EM (2019) The role of relative humidity and cement type on carbonation resistance of concrete. Alexandria Engineering Journal 58(4): 1257-1264, https://doi.org/10. 1016/j.aej.2019.10.008.

Elsener B (2003) Electrochemical techniques for measuring metallic corrosion' recommendations, half-cell potential measurements potential mapping on reinforced concrete structures. Material and Structures 36: 461-471, https://doi.org/10.1617/13718.

Helland S (2013) Service life design of concrete structures: the limit state and reliability-based approach given in fib MC SLD and ISO 16204. International Journal of Structural Engineering 4(1-2): 14-23, https:// doi.org/10.1504/IJSTRUCTE.2013.050761.

Huang Q, Gardoni P and Hurlebaus S (2011) Predicting concrete compressive strength using ultrasonic pulse velocity and rebound number. $A C I$ Materials Journal 108(4): 403-412, https://doi.org/10.14359/51683113.

Hurling H (1984) Oxygen permeability of concrete. In Proceedings of the 1984 RILEM Seminar on the Durability of Concrete Structures under Normal Outdoor Exposure. Institut für Baustoffkunde und Materialprüfung der Universität, Hanover, Germany, pp. 90-101.

Hussain RR (2011a) Effect of moisture variation on oxygen consumption rate of corroding steel in chloride contaminated concrete. Cement and Concrete Composites 33(1): 154-161, https://doi.org/10.1016/j. cemconcomp.2010.09.014.

Hussain RR (2011b) Influence of chloride ions and hot weather on isolated rusting steel bar in concrete based on NDT and electro-chemical model evaluation. NDT \& E International 44(2): 158-162, https://doi.org/10. 1016/j.ndteint.2010.11.010.

Hussain RR (2011c) Electrochemical experimental measurement of macrocell corrosion half-cell potential replicating the re-corrosion of actual refurbished works in RC structures. International Journal of Electrochemical Science 6(1): 199-205.

Hussain RR and Ishida T (2010a) Development of numerical model for FEM computation of oxygen transport through porous media coupled with micro-cell corrosion model of steel in concrete structures. Computers \& Structures 88(9-10): 639-647, https://doi.org/10.1016/j. compstruc.2010.02.008.

Hussain RR and Ishida T (2010b) Novel approach towards calculation of averaged activation energy based on Arrhenius plot for modelling of the effect of temperature on chloride induced corrosion of steel in concrete. Journal of ASTM International 7(5): 1-8, https://doi.org/10. 1520/JAI102667.

Hussain RR and Ishida T (2011a) Enhanced electro-chemical corrosion model for reinforced concrete under severe coupled actions of chloride and temperature. Construction and Building Materials 25(3): 1305-1315, https://doi.org/10.1016/j.conbuildmat.2010.09.014.

Hussain RR and Ishida T (2011b) Investigation of volumetric effect of coarse aggregate on corroding steel reinforcement at the interfacial transition zone of concrete. KSCE Journal of Civil Engineering 15(1): 153-160, https://doi.org/10.1007/s12205-011-1035-x.

ISO (International Organization for Standardization) (2012) ISO/CD 16204:2012: Durability - service life design of concrete structures. ISO, Geneva, Switzerland.

Jayasree S, Ganesan N and Abraham R (2016) Effect of ferrocement jacketing on the flexural behaviour of beams with corroded reinforcements. Construction and Building Materials 121: 92-99, https://doi.org/10.1016/j.conbuildmat.2016.05.131.

Leslie JR and Cheesman WJ (1949) An ultrasonic method of studying deterioration and cracking in concrete structures. Journal of the American Concrete Institute 21(1): 17-36, https://doi.org/10.14359/12041.

Li G, Hu F and Wu Y (2011) Chloride ion penetration in stressed concrete. Journal of Materials in Civil Engineering 23(8): 1145-1153, https:// doi.org/10.1061/(ASCE)MT.1943-5533.0000281.

Mahmood A, Mahmoud Ahmed N, Fong Kwong Y et al. (2014) Applications of the image processing method on the structure measurements in porous GaN. Journal of Experimental Nanoscience 9(1): 87-95, https://doi.org/10.1080/17458080.2013.814173.

Maruya T, Hsu K, Takeda H and Tangtermsiriku S (2003) Numerical modeling of steel corrosion in concrete structures due to chloride ion, oxygen and water movement. Journal of Advanced Concrete Technology 1(2): 147-160, https://doi.org/10.3151/jact.1.147.

Monteiro A, Gonçalves A and Engenharia ND (2009) Assessment of characteristic compressive strength in structures by the rebound hammer test according to EN 13791: 2007. In Proceedings of NDTCE'09, Non-destructive Testing in Civil Engineering. Actes des Journées Scientifiques du LCPC, Nantes, France, pp. 249-254.

Muigai R, Moyo P and Alexander M (2012) Durability design of reinforced concrete structures: a comparison of the use of durability indexes in the deemed-to-satisfy approach and the full-probabilistic approach. Materials and Structures 45(8): 1233-1244, https://doi.org/ 10.1617/s11527-012-9829-y.

Otieno M, Ikotun J and Ballim Y (2019) Experimental investigations on the influence of cover depth and concrete quality on time to cover cracking due to carbonation-induced corrosion of steel in RC structures in an urban, inland environment. Construction and Building Materials 198: 172-181, https://doi.org/10.1016/j.conbuildmat.2018. 11.215 .

Qin X, Meng S, Cao D et al. (2016) Evaluation of freeze-thaw damage on concrete material and prestressed concrete specimens. Construction and Building Materials 125: 892-904, https://doi.org/10.1016/j. conbuildmat.2016.08.098.

Raupach M (1996a) Investigations on the influence of oxygen on corrosion of steel in concrete - Part 1. Materials and Structures 29(3) 174-184, https://doi.org/10.1007/BF02486163.

Raupach M (1996b) Investigations on the influence of oxygen on corrosion of steel in concrete - Part 2. Materials and Structures 29(4): 226-232, https://doi.org/10.1007/BF02485944.

Shruti S and Mukherjee A (2011) Monitoring corrosion in oxide and chloride environments using ultrasonic guided waves. Journal of Materials in Civil Engineering 23(2): 207-211, https://doi.org/10. 1061/(ASCE)MT.1943-5533.0000144.

Verma SK, Bhadauria SS and Akhtar S (2014) Monitoring corrosion of steel bars in reinforced concrete structures. Scientific World Journal 2014: article 957904, https://doi.org/10.1155/2014/957904. 
Wasim M, Ngo TD and Abid M (2020) Investigation of long-term corrosion resistance of reinforced concrete structures constructed with various types of concretes in marine and various climate environments. Construction and Building Materials 237: article 117701, https://doi.org/10.1016/j.conbuildmat.2019.117701.

Xiong Y, Wu D, Tang Y, Hu M and Shu H (2017) Experimental studies on mechanical properties of corroded steel bars after elevated temperature. Procedia Engineering 210: 622-629, https://doi.org/10. 1016/j.proeng.2017.11.122.

Yodsudjai W and Pattarakittam T (2017) Factors influencing half-cell potential measurement and its relationship with corrosion level. Measurement 104: 159-168, https://doi.org/10.1016/j.measurement. 2017.03.027.

\section{How can you contribute?}

To discuss this paper, please email up to 500 words to the editor at journals@ice.org.uk. Your contribution will be forwarded to the author(s) for a reply and, if considered appropriate by the editorial board, it will be published as discussion in a future issue of the journal.

Proceedings journals rely entirely on contributions from the civil engineering profession (and allied disciplines). Information about how to submit your paper online is available at www.icevirtuallibrary.com/page/authors, where you will also find detailed author guidelines. 